ROCZNIK ADMINISTRACJI PUBLICZNEJ 2020 (6)

ARTYKUtY / ARTICLES

Administracyjne prawo materialne

Administrative material law

KacPer ChOLEWA'

\title{
Społeczno-prawna sytuacja dziecka w Polsce w XXI w. - formy dyskryminacji małoletnich i sposoby rozwiązywania konfliktów z ich udziałem
}

\section{Ewolucja międzynarodowego systemu prawnego}

Ochrona praw dziecka jest ogólnoświatowym problemem, wokół którego zrzeszyła się działalność organizacji pozarządowych oraz państw. W opinii publicznej można usłyszeć hasła typu „dzieci przyszłością narodu” - należy jednak zauważyć, że dzieci są także tu i teraz, częstokroć porzucone przez rodziców oraz zaniedbywane przez organy państwowe. Z tych właśnie względów, zasadnym wydaje się być poddanie analizie aktualnej sytuacji prawnej i społecznej małoletnich w Rzeczypospolitej Polskiej, celem określenia głównych problemów, jakie towarzyszą im w XXI w. oraz sformułowania postulatów umożliwiających sprawne rozwiązywanie konfliktów z udziałem małoletnich, a także zasad i rozwiązań prawnych, które uniemożliwią dyskryminację dzieci w społeczeństwie.

Szczególne zainteresowanie tematyką problemów ochrony małoletnich, zauważyć można końcem XIX w., kiedy to w Stanach Zjednoczonych powstała pierwsza organizacja działająca na rzecz zapewnienia dzieciom należytych im praw - New York Society for the Prevention of Cruelty to Children². Szczególny wyraz starań organizacji państwowych ku zapewnieniu dzieciom godnego bytu widoczny jest w postanowieniach Deklaracji Genewskiej z 1924 r. - pierwszej tego typu kodyfikacji stanowiącej zalążek formalnoprawnego podejścia do problemów nieletnich. Postanowienia ww. aktu prawnego odnosiły się przede wszystkim do zapewnienia dziecku możliwości normalnego rozwoju fizycznego i duchowego, w zgodzie

1 Mgr Kacper Cholewa, Instytut Prawa i Ekonomii, Uniwersytet Pedagogiczny im. Komisji Edukacji Narodowej w Krakowie.

2 A. Krawczak-Chmielecka, O rozwoju praw dziecka w Polsce i na świecie, Dziecko Krzywdzone. Teoria, badania i praktyka Vol. 16 Nr 2 (2017), https://dzieckokrzywdzone.fdds.pl/index.php/DK/article/view/629/488, s. 12. 
ze swymi przekonaniami ${ }^{3}$. Deklaracja podniosła problem ochrony życia i zdrowia dzieci oraz potrzeby prawidłowego przygotowania małoletnich do wejścia w dorosłe życie ${ }^{4}$.

Rozwój cywilizacji i rozwój świadomości społecznej spowodował stopniowe rozwinięcie ogólnikowych stwierdzeń Deklaracji Genewskiej w uchwalonej przez Zgromadzenie Ogólne ONZ dnia 20 listopada 1959 r. Deklaracji Praw Dziecka ${ }^{5}$ - tj. dokumentu zawierającego 10 zasad dot. należytego sprawowania pieczy nad dziećmi i zapewnienia im dogodnych warunków do godnego rozwoju. Aktu uchwalonego zgodnie z treścią preambuły z powodu potrzeby zapewnienia małoletnim - w związku z ich niedojrzałością fizyczną i umysłową - należytej opieki i troski, a także odpowiedniej opieki prawnej zarówno przed urodzeniem jak i po przyjściu na świat.

Jednym $\mathrm{z}$ istotnych aktorów sceny międzynarodowej, w dążeniach do zapewnienia dzieciom należytego im szacunku i odpowiednich warunków bytowych była i jest Polska. To właśnie Polska w 1978 r. złożyła pierwszy projekt Konwencji o prawach dziecka, opracowany ostatecznie i uchwalony przez ONZ 20 listopada 1989 r. ${ }^{6}$. Wraz z kolejnymi aktami prawnymi regulującymi sytuację prawną dzieci, coraz bardziej kładziono nacisk na społeczne znaczenie prawidłowego rozwoju dziecka oraz na jego przyszły wkład w rozwój dobra wspólnego. Dostrzegalny stał się, także trend wskazujący na potrzebę zapewnienia małoletnim warunków bytowych umożliwiających indywidualne ukształtowanie jednostki zgodnie $\mathrm{z}$ jej przekonaniami.

Mówiąc o dorobku prawnym i naukowym na rzecz ochrony praw dziecka w Polsce, nie sposób pominąć postaci Janusza Korczaka. Słynnego autora myśli „nie ma dzieci - są ludzie”. W swym opracowaniu Jak kochać dziecko. Dziecko w rodzinie - Korczak pisze: „chcę, by zrozumiano, że żadna książka, żaden lekarz nie zastąpią własnej czujnej myśli, własnego spostrzeżenia”. To kluczowe zdanie oddające w pełni sens rodzicielstwa i życia w rodzinie. Wydaje się, że szczególnie istotne w XXI w. - wieku postępującej cyfryzacji i globalizacji, wieku społeczeństwa konsumpcyjnego, nieustannie goniącego za zyskiem i samorozwojem. Wartości niegdyś ważne, takie jak rodzina, dziś odchodzą na dalszy tor ustępując np. rozwoju kariery. Coraz więcej społeczeństw boryka się z problemem starzenia się. Wśród nich, jest także Polska. Należy bowiem zauważyć, że od 1990 r. w Polsce nieustannie od-

3 Strona Internetowa Funduszu Narodów Zjednoczonych na Rzecz Dzieci, https:// www.unicef.pl/content/download/11454/94626/file/Microsoft_Word_-_Deklaracja_ Genewska.pdf (25.06.2020).

4 Ibidem.

5 Deklaracja Praw Dziecka Uchwalona przez ONZ dnia 20 listopada 1959 r., http:// libr.sejm.gov.pl/tek01/txt/onz/1959.html (26.06.2020).

6 Konwencja o Prawach Dziecka przyjęta przez Zgromadzenie ONZ dnia 20 listopada 1989 r. (Dz U. 1991 Nr 120 poz. 526). 
notowuje się ujemny przyrost demograficzny ${ }^{7}$. Poziom dzietności w latach 90tych wynosił około dwóch urodzeń przypadających na jedną kobietę dziś jest to tylko $1.43^{8}$.

\section{Społeczno-prawna sytuacja dziecka w Polsce}

Analizując społeczno-prawną sytuację dziecka w Polsce należy w pierwszej kolejności sięgnąć do najważniejszego źródła polskiego prawa - Konstytucji Rzeczypospolitej Polskiej z dnia 2 kwietnia 1997 r., która w swym art. 30 stanowi o przyrodzonej i niezbywalnej godności człowieka - a więc także i dziecka. Godność ta stanowi źródło jego wolności i praw określonych m.in. w Europejskiej Konwencji Praw Człowieka, wymienionej na wstępie Konwencji o Prawach Dziecka oraz tych obywatelskich. Należy zauważyć, że poszanowanie i ochrona ww. wartości stanowi obowiązek władz publicznych, zgodnie bowiem $\mathrm{z}$ art. 18 Konstytucji RP, rodzina, macierzyństwo i rodzicielstwo znajdują się pod ochroną i opieką Rzeczypospolitej Polskiej. Prawa wynikające $z$ norm konstytucyjnych są przyrodzone i niezbywalne, a na szczególne uwzględnienie zasługuje norma art. 72 Konstytucji RP, odnoszącego się bezpośrednio do małoletnich - „Rzeczpospolita Polska zapewnia ochronę praw dziecka. Każdy ma prawo żądać od organów władzy publicznej ochrony dziecka przed przemocą, okrucieństwem, wyzyskiem i demoralizacją". Zapis ten został określony szeroko, ponieważ dotyczy zarówno ochrony przed zagrożeniami o charakterze fizycznym takimi jak przemoc, okrucieństwo, znęcanie się i wyzysk, jak i zagrożeniami o charakterze psychicznym bądź wpływającymi negatywnie na kształtowanie postaw moralnych nieletnich ${ }^{9}$. Wspomniany przepis Konstytucji został skonkretyzowany ustawą z dnia 6 stycznia 2000 r. o Rzeczniku Praw Dziecka, w drodze której powołany został organ do kontroli przestrzegania praw dziecka, obowiązany do podejmowania działań zmierzających do zapewnienia dziecku pełnego i harmonijnego rozwoju $\mathrm{z}$ poszanowaniem jego godności i praw podmiotowych. Organ ten powinien kierować się, zgodnie $\mathrm{z}$ art. 1 ust. 3 ww. ustawy, przede wszystkim dobrem dziecka. Rzecznik podejmuje bowiem działania w szczególności na rzecz ochrony prawa do

7 Bank Światowy, Dane statystyczne dot. tempa wzrostu liczby ludności, https:// www.google.com/publicdata/explore?ds=d5bncppjof8f9_\&met_y=sp_pop_grow\&idi$\mathrm{m}=$ country:POL:ITA:SWE\&hl=pl\&dl=pl, 8 kwietnia 2020 (25.06.2020).

8 Bank Światowy, Dane statystyczne dot. wskaźnika płodności, https://www.google.com/publicdata/explore?ds=d5bncppjof8f9_\&met_y=sp_dyn_tfrt_in\&idim=country:POL:ITA:SWE \&hl $=$ pl\&dl=pl\#!ctype $=1 \&$ strail $=$ false $\& b c s=d \& n s e l m=$ h \&met $\mathrm{y}=$ sp_dyn_tfrt_in\&scale_y=lin\&ind_y=false\&rdim=world\&idim =country:POL\&ifdi$\mathrm{m}=$ world\&hl=pl\&dl=pl\&ind=false, 8 kwietnia 2020, (26.06.2020).

9 B. Banaszak, Ł. Żukowski, Prawo dziecka do ochrony przed przemoca, okrucieństwem, wyzyskiem i demoralizacja - rozwiazania polskie na tle standardów Konwencji o Prawach Dziecka, S. Stadniczeńko (red.), Warszawa 2015, s. 237-238. 
życia i ochrony zdrowia, prawa do wychowania w rodzinie, prawa do godziwych warunków socjalnych oraz prawa do nauki ${ }^{10}$. Rzecznik obowiązany jest szczególną troską i pomocą otaczać dzieci niepełnosprawne oraz podejmować działania zmierzające do ochrony dziecka przed przemocą, okrucieństwem, wyzyskiem, demoralizacją, zaniedbaniem i złym traktowaniem $^{11}$. Rzecznik swoje zadanie pełni na podstawie kompetencji Rzecznika Praw Dziecka wymienionych w art. 10 ustawy, do najważniejszych z nich należy zaliczyć: prawo do zbadania, nawet bez uprzedzenia, każdej sprawy na miejscu; prawo do żądania od organów władzy publicznej, organizacji lub instytucji złożenia wyjaśnień, udzielenia informacji lub udostępnienia akt i dokumentów oraz prawo do wzięcia udziału w postępowaniu w sprawach nieletnich na prawach prokuratora ${ }^{12}$.

Racjonalny ustrojodawca w art. 72 ust. 2. Konstytucji RP przewidział, także formę ochrony praw dzieci pozbawionych opieki rodzicielskiej. Wymieniony zapis Konstytucji nakłada na organy władzy publicznej szczególny obowiązek zagwarantowania pomocy dzieciom pozbawionym opieki rodziców. Działanie ustrojodawcy wydaje się być uzasadnione i celowe. Z danych Głównego Urzędu Statystycznego wynika, bowiem, że w 2018 r. blisko 71800 dzieci pozostawało w pieczy zastępczej ${ }^{13}$. W Polsce opieka ta przyjmuje formę zarówno rodzinnej pieczy zastępczej, z której w 2018 r. skorzystało 55152 dzieci, jak i pieczy instytucjonalnej, w ramach której funkcjonowały 1152 placówki opiekuńczo-wychowawcze, pełniące funkcję placówek socjalizacyjnych, rodzinnych, interwencyjnych oraz placówek łączących zadania, zapewniając łącznie opiekę 16700 dzieciom $^{14}$.

Ww. instytucje działają na podstawie ustawy z dnia 9 czerwca $2011 \mathrm{r}$. o wspieraniu rodziny i pieczy zastępczej - aktu prawnego uchwalonego zgodnie z treścią preambuły „dla dobra dzieci, które potrzebują szczególnej ochrony i pomocy ze strony dorosłych, środowiska rodzinnego, atmosfery szczęścia, miłości i zrozumienia, w trosce o ich harmonijny rozwój i przyszłą samodzielność życiową, dla zapewnienia ochrony przysługujących im praw i wolności”"15.

10 Ustawa z dnia 6 stycznia 2000 r. o Rzeczniku Praw Dziecka (Dz. U. 2020 poz. 141), art. 3 ust. 2.

11 Ibidem, art. 3. ust. 4 i 5.

12 Ibidem, art. 10.

13 Główny Urząd Statystyczny, Piecza zastępcza w 2018 roku, https://stat.gov.pl/ obszary-tematyczne/dzieci-i-rodzina/dzieci/piecza-zastepcza-w-2018-roku,1,3.html, s. $1,(25.06 .2020)$.

14 Ibidem.

15 Ustawa z dnia 9 czerwca 2011 r. o wspieraniu rodziny i pieczy zastępczej (Dz. U. z 2020 r., poz. 821). 


\section{Formy dyskryminacji dzieci w XXI w.}

Dyskryminacja jest pojęciem złożonym, często rozumianym niejednoznacznie - to kategoria zarówno socjologiczna, jak i prawna ${ }^{16}$. Wyróżniamy dyskryminację bezpośrednią, która ma miejsce wówczas, gdy ze względu na jaką́s konkretną cechę (np. pochodzenie) dana osoba jest mniej korzystnie traktowana od innej osoby w porównywalnej sytuacji oraz dyskryminację pośrednią, z którą mamy do czynienia, gdy jakieś pozornie neutralne postanowienie prawne przyczynia się do powstania niekorzystnej sytuacji danej osoby w porównaniu $\mathrm{z}$ innymi osobami ${ }^{17}$.

We współczesnym świecie można wyróżnić wiele rodzajów dyskryminacji - bardzo często problem ten dotyka także dzieci. Jedną z najbardziej szkodliwych form dyskryminacji wydaje się być instytucjonalna. Charakteryzująca się uprzywilejowaniem jednej kategorii osób lub grupy społecznej, kosztem innej - zazwyczaj poprzez prowadzenie konkretnego rodzaju polityki uwidaczniającej preferowane przez władzę poglądy, czy kierunki rozwoju państwa oraz społeczeństwa. Dyskryminacja instytucjonalna w znacznej mierze opiera się na autorytecie państwa, są to działania stanowiące swego rodzaju absurd lub wręcz patologię. Należy wskazać, że od władz bardziej niż od obywateli wymaga się zachowywania pewnych standardów i postępowania mającego służyć za przykład, tym bardziej że Konstytucja RP nakłada na organy władzy publicznej wyraźny konstytucyjny obowiązek do przestrzegania pewnych standardów, m.in. do zapewnienia opieki i pomocy dzieciom pozbawionym opieki rodzicielskiej, o którym była już mowa we wcześniejszej części tekstu. Tymczasem nieprawidłowości w działaniach państwa można doszukać się zarówno na poziomie władzy centralnej - tj. Parlamentu, jak i tej na niższych szczeblach. Co istotne, przykłady zaniedbań można wskazać, także w działalności organu specjalnie powołanego do ochrony dzieci przed zaniedbaniem i demoralizacją - Rzecznika Praw Dziecka. O czym świadczy m.in. potrzeba zaangażowania Rzecznika Praw Obywatelskich w kwestie związane z wdrażaniem programów socjalnych mających wspierać rozwój dzieci oraz ich rodzin, w stosunku do których pomimo licznych protestów i sygnałów alarmujących, Rzecznik Praw Dziecka nie zabrał głosu. Należy zauważyć, że programy rządowe takie jak „500+” i „wyprawka szkolna”, niewątpliwie przyniosły poprawę sytuacji materialnej rodzin ${ }^{18}$. Jednakże należy wskazać na liczne nieprawidłowości towarzyszące ich wprowadzaniu. M.in. naru-

16 Ł. Łatocki, Integracja i dyskryminacja - krajobraz 2009. Raport Instytutu Spraw Publicznych, Instytut Spraw Publicznych, Warszawa 2009 r., s. 12.

17 Ibidem, s. 24.

18 D. Gajos-Kaniewska, Dlaczego dzieci z domów dziecka nie są objęte 500+ - ministerstwo rodziny wyjaśnia, https://www.rp.pl/Praca-emerytury-renty/307169957-Dlaczego-dzieci-z-domu-dziecka-nie-sa-objete-500---ministerstwo-rodziny-wyjasnia. html (25.06.2020). 
szenie konstytucyjnej zasady sprawiedliwości społecznej wynikającej z art. 2 Konstytucji RP, poprzez różnicowanie dzieci w zależności od ich liczby $\mathrm{w}$ rodzinie oraz tego czy rodzinę posiadają. W pierwotnej fazie funkcjonowania programu „500+” tj. w latach 2016-2019, dzieci z domów dziecka nie były nimi objęte. Pomimo iż dzieci znajdujące się w analogicznej sytuacji przebywające $\mathrm{w}$ ramach rodzinnej pieczy zastępczej, były uprawnione do pobierania tego świadczenia. Sytuacja zmieniła się dopiero po 3 latach funkcjonowania programu - 1 lipca 2019 r. ${ }^{19}$.

Pomimo wcześniejszego doświadczenia związanego z funkcjonowaniem i wdrażaniem 500+, w ramach programu Dobry Start, ustawodawca również dążył do ponownego różnicowania pozycji dzieci. W trakcie trwania prac nad ustawą, w jej projekcie, dzieci z domów dziecka ponownie zostały pominięte ${ }^{20}$. Wywołało to kolejną interwencję Rzecznika Praw Obywatelskich, która w efekcie pozwoliła na ostateczne przyjęcie ustawy $\mathrm{w}$ zgodzie z konstytucyjnymi zapisami, bez nieuzasadnionego różnicowania, które to doświadczonym i tak przez los dzieciom z domów dziecka na pewno nie pomagało $\mathrm{w}$ prawidłowym odnalezieniu się $\mathrm{w}$ ramach swoich ról społecznych ${ }^{21}$.

Kolejnym istotnym problemem dotykającym dzisiejszy świat i jego mieszkańców jest zjawisko dyskryminacji rówieśniczej. Dzieci bardzo wiele wzorców czerpią z domu oraz szkoły, obydwa środowiska stanowią integralną część procesu wychowania i edukacji dzieci oraz młodzieży. Funkcjonują razem, odkąd odpowiedzialność za wychowanie dziecka powierzono częściowo pedagogom $\mathrm{w}$ ramach placówek edukacyjnych ${ }^{22}$. W związku z powyższym należy szczególną troską otoczyć te właśnie miejsca. Strzec ich przed dyskryminacją, agresją oraz innymi negatywnymi czynnikami mogącymi zaburzyć prawidłowy rozwój przebywających tam dzieci. Placówki wychowawcze oraz domy rodzinne należy otaczać szczególną troską i zainteresowaniem. Szkoły i placówki publiczne powinny umożliwiać podtrzymanie poczucia tożsamości narodowej, etnicznej oraz językowej uczniów, a także ich przekonań i wartości, które wyznająa2 . Wyniki badania

19 W. Ziomek, 500 + także dla wychowanków domów dziecka. Placówki składaja wnioski, https://www.money.pl/gospodarka/500-takze-dla-wychowankow-domow-dziecka-placowki-skladaja-wnioski-6401507587463297a.html (25.06.2020).

20 P. Ciszak, 300+ nie dla dzieci z domów dziecka. Rzecznik Praw Obywatelskich interweniuje u ministra, https://www.money.pl/gospodarka/wiadomosci/artykul/ 300-nie-dla-dzieci-z-domu-dziecka-rzecznik,22,0,2403606.html (25.05.2020).

21 J. Bereźnicki, Wyprawka 300+ także dla dzieci z domów dziecka. Pieniądze będą dostawać do 20 roku życia, https://finanse.wp.pl/wyprawka-300-takze-dla-dzieci-z-domow-dziecka-pieniadze-beda-dostawac-do-20-roku-zycia-6262414118192769a (26.06.2020).

22 P. Młynek, Współpraca rodziców i nauczycieli - charakter, oczekiwania i uwarunkowania, Katowice 2017, https://sbc.org.pl/Content/296920/doktorat3899.pdf (27.06.2020).

23 Ł. Łotocki, Integracja i dyskryminacja - krajobraz 2009. Raport Instytutu Spraw Publicznych, Instytut Spraw Publicznych, Warszawa 2009 r., s. 66. 
„Dyskryminacja w szkole - obecność nieusprawiedliwiona” realizowanego w 2015 r., wskazują, że niestety w praktyce szkoła nie zawsze stanowi bezpieczne środowisko, a dyskryminacja w szkole przybiera bardzo różne formy - począwszy od izolacji, poprzez wyśmiewanie, wyzywanie, obrażanie, ocenianie, deprecjonujące komentarze - po wywyższanie się, stosowanie paternalistycznych postaw i dyscyplinowanie do „normalności”, ale także faworyzowania przez nauczycieli, braku zrozumienia a nawet przemoc fizyczną i seksualną ${ }^{24}$.

\section{Sposoby rozwiązywania konfliktów małoletnich}

Bardzo ważnym zapisem Konstytucji RP, na który należy zwrócić szczególną uwagę przy ocenie sytuacji prawnej dziecka w Polsce oraz analizowaniu narzędzi przydatnych do rozwiązywania zarówno konfliktów, jak i problemu dyskryminacji jest art. 72. ust. 3., określający sytuację prawną dziecka w toku ustalania jego praw, m.in. przed sądem oraz innymi organami władzy państwowej. Przepis ten stanowi o obowiązku organów władzy publicznej oraz osoby odpowiedzialnej za dziecko, do wysłuchania i w miarę możliwości rozsądnego uwzględnienia zdania dziecka w toku postępowania. W pierwszej kolejności należy więc wskazać, że dziecko nie powinno być wyłączane ze sporu dotyczącego rozwiązania wynikającej z jego powodu sprawy, o ile oczywiście nie sprzeciwiają się temu względy dobra małoletniego.

Poddając analizie wskazane rozwiązanie prawne, szczególną uwagę należy przywiązać do postępowań w sprawach rodzinnych i nieletnich, a także różnego rodzaju konfliktów rówieśniczych. Tematy te wydają się być szczególnie istotne z powodu ich doniosłości społecznej oraz znacznej ilości spraw trafiających zarówno przed sądy powszechne, jak i do kierowników placówek opiekuńczo-wychowawczych, takich jak szkoły, czy ośrodki pełniące pieczę zastępczą.

Należy zauważyć, że w latach 2002-2017, sądy powszechne, rozpatrujące sprawy rodzinne i nieletnich, $\mathrm{z}$ roku na rok przyjmowały coraz to więcej spraw $^{25}$. Jednak, co ciekawe, coraz mniej jest $\mathrm{w}$ sądach spraw nieletnich, bowiem od 2013 r. uwidoczniła się wyraźna tendencja spadkowa dobrze widoczna w poniższej tabeli:

24 K. Gawlicz (red.), Dyskryminacja w szkole - obecność nieusprawiedliwiona. O budowie edukacji antydyskryminacyjnej $w$ systemie edukacji formalnej $w$ Polsce, Towarzystwo Edukacji Antydyskryminacyjnej, Warszawa 2015, s. 96-97.

25 A. Siemaszko, P. Ostaszewski, J. Włodarczyk-Madejska, Tendencje wpływu spraw do polskich sądów powszechnych, Analizy wymiaru sprawiedliwości, Warszawa 2019, s. 66. 
Tabela 1. Wpływ spraw rodzinnych i nieletnich do sądów powszechnych

\begin{tabular}{|c|c|c|c|c|}
\cline { 2 - 5 } \multicolumn{2}{c|}{} & Ogółem & Rodzinne & Nieletnich \\
\hline \multirow{2}{*}{2002} & $\mathrm{~N}$ & 616741 & 495541 & 121200 \\
\cline { 2 - 5 } & $\%$ & 100,0 & 80,3 & 19,7 \\
\hline 2003 & $\mathrm{~N}$ & 626118 & 499400 & 126718 \\
\hline 2004 & $\mathrm{~N}$ & 571039 & 430677 & 140362 \\
\hline 2005 & $\mathrm{~N}$ & 622434 & 482598 & 139836 \\
\hline 2006 & $\mathrm{~N}$ & 648584 & 496396 & 152188 \\
\hline 2007 & $\mathrm{~N}$ & 675303 & 509726 & 165577 \\
\hline $200 \mathrm{~S}$ & $\mathrm{~N}$ & 731283 & 567469 & 163814 \\
\hline 2009 & $\mathrm{~N}$ & 746098 & 590548 & 155550 \\
\hline 2010 & $\mathrm{~N}$ & 732003 & 583000 & 149003 \\
\hline 2011 & $\mathrm{~N}$ & 754910 & 607118 & 147792 \\
\hline 2012 & $\mathrm{~N}$ & 760610 & 621932 & 138678 \\
\hline 2013 & $\mathrm{~N}$ & 790875 & 659210 & 131665 \\
\hline 2014 & $\mathrm{~N}$ & 746161 & 648473 & 97688 \\
\hline 2015 & $\mathrm{~N}$ & 737147 & 658280 & 78867 \\
\hline 2016 & $\mathrm{~N}$ & 681575 & 612219 & 70478 \\
\hline \multirow{2}{*}{2017} & $\mathrm{~N}$ & 723376 & 652898 & 9,7 \\
\cline { 2 - 5 } & $\%$ & 100,0 & 90,3 & - \\
\hline \multirow{2}{*}{ wskaźnik } & & & 131,8 & \\
dynamiki & 117,3 & & \\
\hline $2002-2017$ & & & \\
\hline
\end{tabular}

Źródło: A. Siemaszko, P. Ostaszewski, J. Włodarczyk-Madejska, Tendencje wpływu spraw do polskich sądów powszechnych, Analizy wymiaru sprawiedliwości, Warszawa 2019, s. 66.

Fakt malejącego wpływu spraw nieletnich może napawać optymizmem. Należy bowiem zauważyć, że skierowanie sprawy na drogę sądową powinno być ostatecznością, niesie bowiem za sobą duży impuls emocji a konsekwencje orzeczenia sądu bardzo często ciągną się za małoletnim, aż do momentu zatarcia ewentualnego skazania.

Należy także zauważyć, że sądy powszechne w Polsce rozpatrują tysiące spraw rozwodowych i o separację, w których to sytuacja dzieci wydaje się być szczególna. Co prawda od 2011 roku notujemy systematyczny spadek wpływu spraw rozwodowych i o separacje, jednakże problemu z nimi związanego nie należy bagatelizowaćéc.

Podjęcie decyzji o rozwodzie częstokroć determinuje dalsze życie dziecka - bardzo często aż do okresu uzyskania przez nie pełnoletniości. Co więcej, rozwód jest procesem, który często trawa nawet kilka lat i przebiega dynamicznie w zależności od stanowiska stron.

26 Departament Strategii i Funduszy Europejskich, Wydział Statystycznej Informacji Zarządczej, Statystyka sądowa sprawy cywilne o rozwód i separację oraz alimenty w latach 2011-2017, Warszawa 2018, s. 11. 


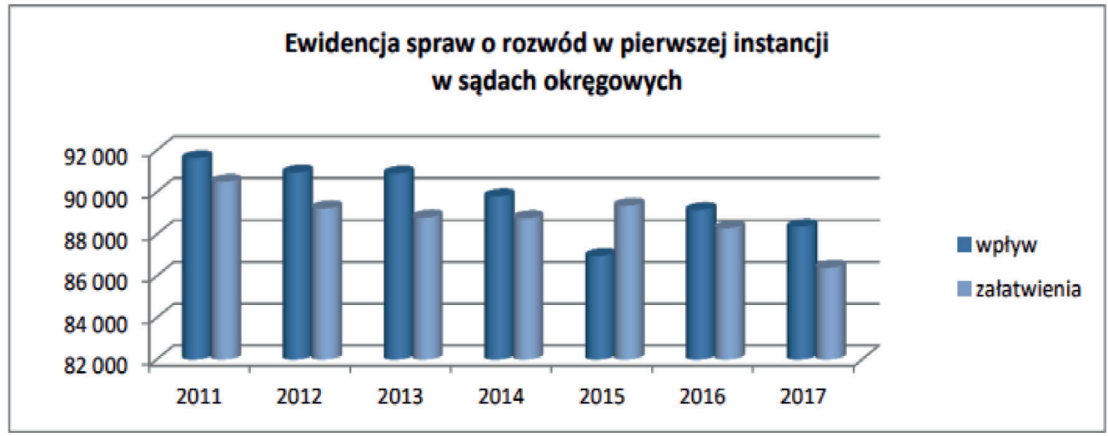

Źródło: Departament Strategii i Funduszy Europejskich, Wydział Statystycznej Informacji Zarządczej, Statystyka sq̨dowa sprawy cywilne o rozwód i separację oraz alimenty w latach 2011-2017, Warszawa 2018, s. 11.

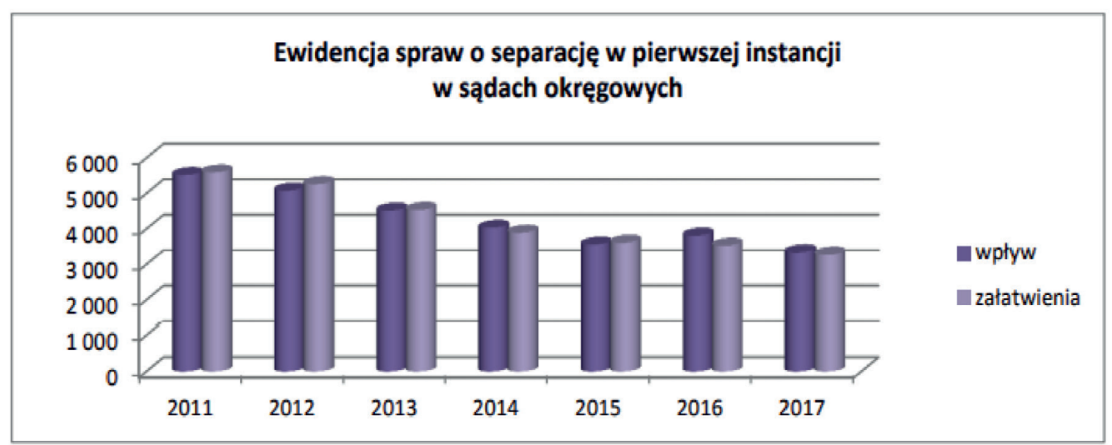

Źródło: Departament Strategii i Funduszy Europejskich, Wydział Statystycznej Informacji Zarządczej, Statystyka sądowa sprawy cywilne o rozwód i separację oraz alimenty $w$ latach 2011-2017, Warszawa 2018, s. 11.

To, w jaki sposób małoletni przejdą ten trudny okres, zależy od wielu czynników, m.in. wieku, jakości relacji z rodzicami, płci, wcześniejszego podziału obowiązków i przyszłych ról rodziców po rozstaniu. W trakcie rozwodu partnerzy mogą ze sobą walczyć, posuwając się do instrumentalnego traktowania dzieci, mogą też rozstać się, starając się nie przenosić swoich konfliktów na relacje z dziećmi i pomóc im w tym trudnym dla nich okresie. Wskutek rozwodu i wcześniejszego procesu rozpadu rodziny $\mathrm{u}$ wielu dzieci pojawiają się zaburzenia w rozwoju psychicznym, dziecko silnie koncentruje się na konflikcie rodzinnym, zarówno poznawczo, jak i emocjonalnie - ponieważ jedno z rodziców odchodzi, dziecko czuje się odrzucone, może mieć poczucie winy na skutek przekonania, że to ono jest przyczyną rozstania - burzliwy rozwód osłabia mechanizmy radzenia sobie przez dziecko w trudnych sytuacjach, dziecko „grzęźnie” na danym etapie rozwoju, męczy je sytuacja w domu, koncentracja na trudnościach w rodzi- 
nie uniemożliwia angażowanie się w naukę, a gniew często blokuje postępy społeczne i psychiczne powodując wykluczenie lub dobrowolne odsunięcie się od społeczeństwa ${ }^{27}$.

Przy rozwiązywaniu konfliktów z udziałem małoletnich skierowanie sprawy na drogę sądową, zgodnie z tym, co zauważono już wcześniej, powinno stanowić ostateczność. Niezależnie od tego czy chodzi o rozwiązanie konkretnej sprawy rodzinnej, stwierdzenie całkowitego rozpadu pożycia pomiędzy małżonkami, czy rozwiązanie innej sprawy skierowanej przeciwko małoletniemu - tj. niezależnie od kwestii, której ma się dana sprawa tyczyć, o wiele lepszym i mniej inwazyjnym rozwiązaniem jest próba ugodowego dojścia do porozumienia, która angażując w rozwiązanie problemu małoletniego może doprowadzić do o wiele bardziej wymiernych efektów, niż niepodlegające dyskusji orzeczenie sądu.

W XXI w. dostrzega się coraz to większe zainteresowanie, ale także i znaczenie alternatywnych form rozwiązywania sporów m.in. w drodze mediacji, negocjacji czy skierowania sprawy pod rozpoznanie przed sąd arbitrażowy czy koleżeński.

Szczególnie ta pierwsza - mediacja tzw. kultura dialogu i konsensualnego rozwiązywania problemów, stale zyskuje na znaczeniu. Pomimo faktu, że jest to instytucja stosunkowo młoda, bowiem została wprowadzona do polskiego porządku prawnego nowelą kodeksu postępowania cywilnego z dnia 28 lipca 2005 r., to doczekała się już pierwszej, gruntownej nowelizacji dnia 10 września 2015 r., mającej zgodnie z założeniami projektodawcy przyczynić się do szerszego korzystania z mediacji w sprawach cywilnych choć należy zauważyć, że ustawodawca wciąż nie zdecydował się na wprowadzenie tej instytucji jako obligatoryjnej ${ }^{28}$. Ta wciąż pozostaje dobrowolna. zwłaszcza w sprawach rodzinnych jest instytucją stale zyskującą na znaczeniu, co z kolei uwidacznia tabela 2.

Niestety mediacje w sprawach nieletnich nie cieszą się tak wielkim zainteresowaniem jak te rodzinne. Można stwierdzić, że poziom zainteresowania ich wykorzystywaniem jest stały i wciąż niewystarczający, o czym świadczą dane zawarte w tabeli 3.

Zgodnie z postanowieniami Kodeksu Postępowania Cywilnego, na podstawie art. 10 tejże ustawy, Sąd dąży do ugodowego załatwienia sprawy. Odbywa się to poprzez dobrowolny udział zwaśnionych stron w próbie zawarcia porozumienia, np. poprzez wyrażenie zgody na wzięcie udziału w mediacji.

Ciekawą kwestią wydaje się włączanie dzieci w mediację, może to bowiem przynieść szereg wymiernych korzyści: przede wszystkim, dzieci

27 J. Piłat, M. Kazańska-Piłat, Przemoc psychiczna wobec dziecka w sytuacji rozwo$d u$, Świat Problemów, Warszawa 2014, http://www.swiatproblemow.pl/przemoc-psychiczna-wobec-dziecka-w-sytuacji-rozwodu/ (27.06.2020).

28 K. Antolak-Szymanski, O. Piaskowska, Mediacja w postępowaniu cywilnym. Komentarz, Wolters Kluwer, Warszawa 2017, s. 15-21. 


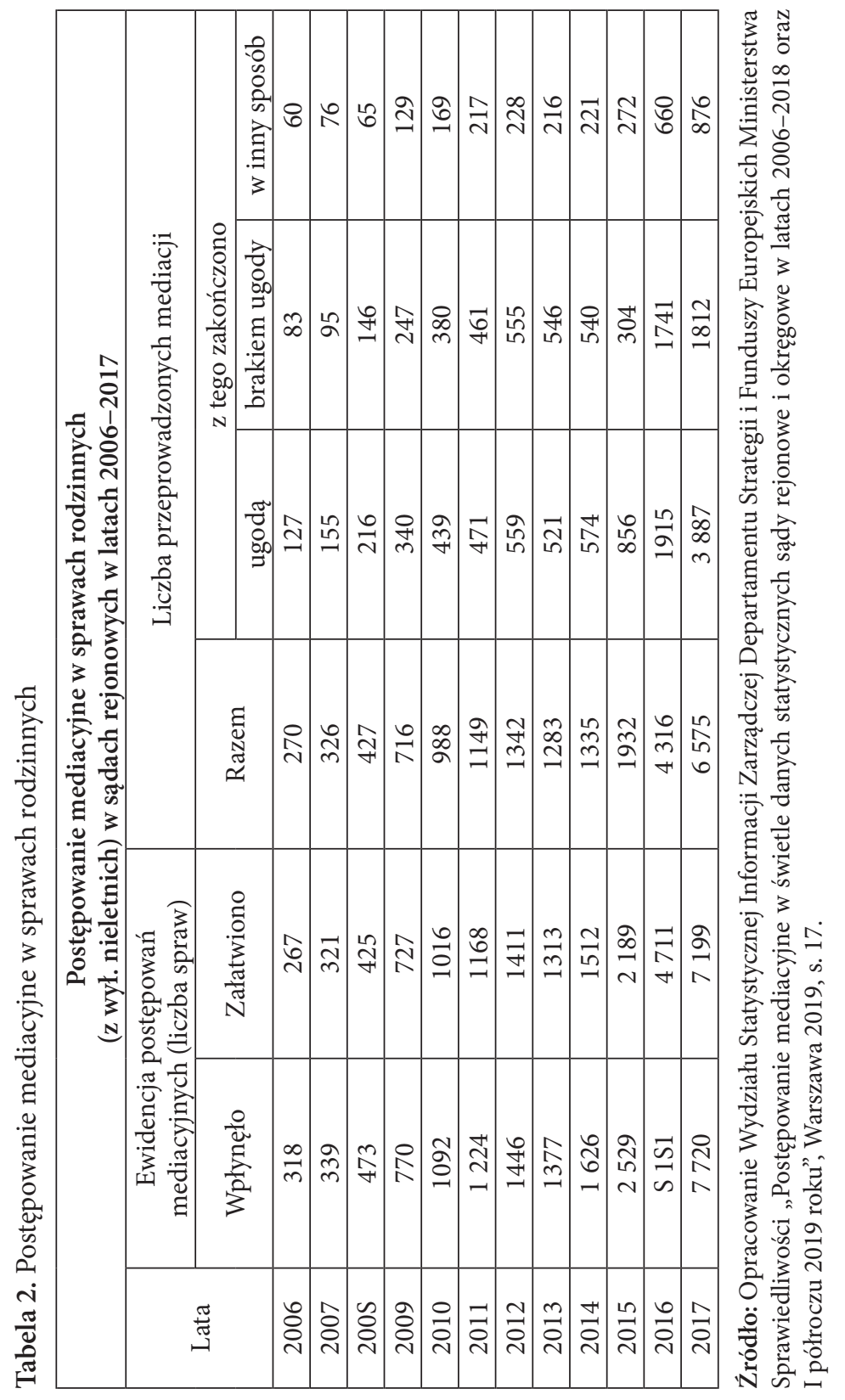




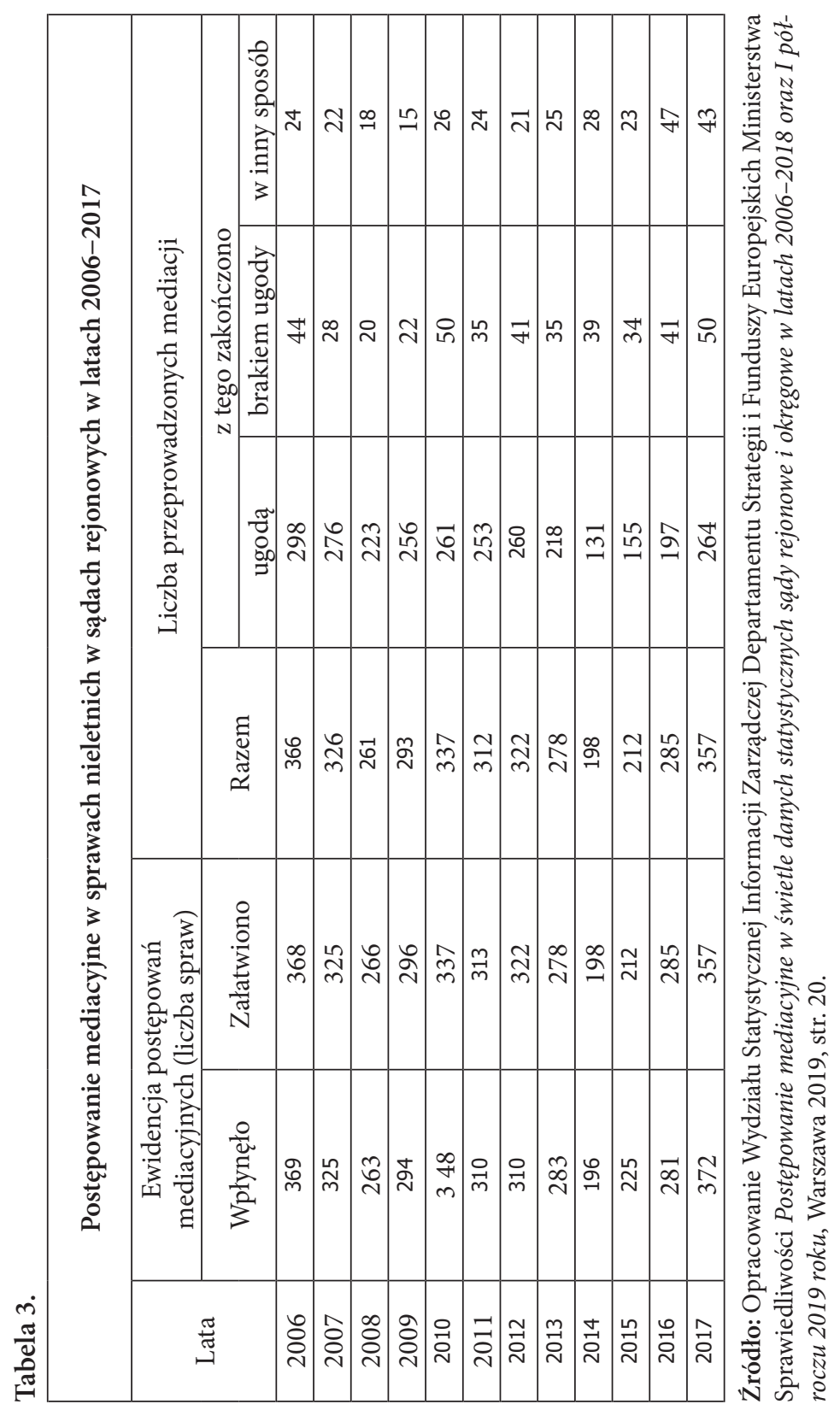


mogą dostarczyć istotnych informacji, niedostępnych z perspektywy rodziców, a kluczowych z punktu widzenia ostatecznych ustaleń ugody mediacyjnej ${ }^{29}$. Dzięki ich udziałowi, mediator może uzyskać wiedzę na temat rzeczywistych potrzeb konkretnego dziecka, jego fazy rozwoju, relacji z rodzicami, co przyczynia się do ustalenia adekwatnego rozwiązania problemu i ułatwia wywiązanie się mediatora $\mathrm{z}$ roli eksploratora problemu ${ }^{30}$. Należy zauważyć, że informacje uzyskane od dziecka pomagają mediatorowi w zachowaniu neutralności, minimalizują bowiem potrzebę poczynania własnych przekonań m.in. na temat prawidłowego sprawowania pieczy rodzicielskiej czy też potrzebę wykorzystywania ogólnodostępnych i specjalistycznych informacji z dziedziny psychologii rozwojowej. Ponadto gdy dziecko wyraża jakieś preferencje, jego obecność zapewnia większe możliwości rozwiązania sporu oraz istnieje większa możliwość pozytywnej reakcji rodzica na informacje uzyskane bezpośrednio od dziecka na temat jego potrzeb lub możliwych negatywnych konsekwencji określonych ustaleńn ${ }^{31}$.

Stare polskie przysłowie mówi „czym skorupka za młodu nasiąknie tym na starość trąci”, dorośli jako osoby odpowiedzialne powinny dążyć do zapewnienia dziecku odpowiednich warunków do godnego i prawidłowego rozwoju, a nie sabotować proces dorastania ${ }^{32}$.

Bardzo ciekawym narzędziem rozwiązywania konfliktów małoletnich, zwłaszcza w szkołach i innego tego typu placówkach stały się w ostatnim czasie mediacje rówieśnicze oraz mediacje szkolne. Nowatorska metoda rozwiązywania sporów została objęta honorowym patronatem Rzecznika Praw Dziecka, który to w 2017 r. wydał dokument określający standardy mediacji rówieśniczej w szkołach i innych placówkach oświatowych ${ }^{33}$.

Wydaje się, że działanie to było w pełni uzasadnione i celowe, na przestrzeni ostatnich lat wyraźnie widać jak ewoluują zachowania agresywne dzieci i młodzieży w szkole, występują one obok innych form napaści, takich jak agresja werbalna, złośliwe zabieranie rzeczy należących do innych osób, niszczenie przedmiotów, a także wykluczenie z grupy rówieśniczej Być może właśnie mediacje szkolne czy rówieśnicze, opisywane w standardach jako dobrowolne i poufne rozwiązywanie konfliktów, przyczynią się do zahamowania tego negatywnego zjawiska. Szczególnie ciekawe wydają

29 A. Gójska, Udział dzieci w mediacjach okołorozwodowych, Mediator 2004, http://www.smr.org.pl/pdf/med_30.pdf, (27.06.2020), s. 2.

30 Ibidem, s. 2.

31 Ibidem, s. 3 .

32 Wielki słownik języka polskiego, https://wsjp.pl/index.php?id_hasla=2711 (27.06.2020).

33 Rzecznik Praw Dziecka, Standardy mediacji rówieśniczej i szkolnej w szkołach i innych placówkach oświatowych, Warszawa 2017, http://brpd.gov.pl/sites/default/files/ standardy_mediacji_rowiesniczej_i_szkolnej_w_szkolach_0.pdf, (27.06.2020).

34 R. Raszewska-Skałecka, Mediacje rówieśnicze jako instrument przeciwdziałania agresji i rozwiązywania konfliktów w szkole, Mediacje ponad podziałami, Wrocław 2013, s. 72. 
się być mediacje rówieśnicze, zdefiniowane jako dobrowolne i poufne poszukiwanie rozwiązania konfliktu między uczniami, w obecności dwóch bezstronnych i neutralnych mediatorów - uczniów. Należy bowiem stwierdzić, że odpowiednio przygotowany małoletni, stanowiący w danej placówce edukacyjnej autorytet, niewątpliwie jest w stanie w sposób o wiele skuteczniejszy dotrzeć do zwaśnionych stron, niż dorosły, do którego dzieci bardzo często podchodzą z dystansem i brakiem zaufania.

\section{Podsumowanie}

Społeczno-prawna sytuacja dzieci w Polsce, wraz z upływem czasu uległa niewątpliwej ewolucji. W XXI w. dostrzega się odejście od postrzegania małoletniego jako jednostki nieporadne, stymulowane przez rodziców, potrzebujące impulsu kierunkowego. Coraz częściej dostrzega się indywidualne potrzeby, cechy i umiejętności małoletnich, a także obowiązki jakie dorośli posiadają względem swych pociech. Rozwój społeczny i rozwój świadomości społecznej doprowadził do sytuacji, w której dziecko pełni o wiele więcej ról społecznych niż w ubiegłym wieku.

Dzieci czerpią ze wzorców, należy więc zapewniać im te jak najlepsze. Niestety realia, w tym znaczący rozwój agresji, ilość spraw toczących się przed sądami, także tych mediacyjnych, ukazuje jak wiele pozostało jeszcze $\mathrm{w}$ tej kwestii do zrobienia. Zachowania dzieci odzwierciedlają w mikroskali problemy z jakimi borykają się całe społeczności ${ }^{35}$. Należy więc stwierdzić, że potrzebna jest szeroko zakrojona akcja edukacyjna, która umożliwi i wpoi małoletnim odpowiednie standardy ${ }^{36}$. Działania państwa oraz władz publicznych nie mogą pogłębiać powstających patologii. Należy więc stwierdzić, że bezpodstawne zróżnicowanie dzieci, dzielenie ich na te lepsze i gorsze nie wpoi pozytywnych wartości, a wręcz przyczyni się do pogłębiania problemów emocjonalnych oraz intelektualnych małoletnich, którym i tak bardzo często wystarczającą ilość przysparzają świadomie lub nie rodzice, angażując swoje pociechy w prywatne konflikty lub nawet traktując je instrumentalnie, wykorzystując do osiągnięcia własnych celów.

Należy zauważyć, że alternatywne metody rozwiązywania sporów, $\mathrm{w}$ tym przede wszystkim mediacje i mediacje rówieśnicze stanowią o wiele lepszy sposób rozwiązania powstałego konfliktu, niż skierowanie sprawy przed organ sądowy lub zaniechanie działania. Należy promować tę formę rozwiązywania sporów, ponieważ w mediacji nie mamy przegranych, jest to sztuka rozmowy i ugodowego załatwiania wynikłych problemów, pozytywnie kształtująca postawy obywatelskie, wzmacniająca charakter poprzez oddanie stronom możliwości „samodzielnego” rozwiązania swojego sporu przed neutralnym i obiektywnym arbitrem - fachowcem od konfliktów.

35 R. Raszewska-Skałecka, Mediacje rówieśnicze..., s. 72.

36 K. Gawlicz (red.), Dyskryminacja w szkole.., s. 364-368. 


\section{Bibliografia}

Antolak-Szymanski K., Piaskowska O., Mediacja w postępowaniu cywilnym. Komentarz, Wolters Kluwer, Warszawa 2017.

Banaszak B., Żukowski Ł., Prawo dziecka do ochrony przed przemoca, okrucieństwem, wyzyskiem i demoralizacja - rozwiąania polskie na tle standardów Konwencji o Prawach Dziecka, Stadniczeńko S. (red.), Warszawa 2015.

Departament Strategii i Funduszy Europejskich, Wydział Statystycznej Informacji Zarządczej, Statystyka sądowa sprawy cywilne o rozwód i separację oraz alimenty $w$ latach 2011-2017, Warszawa 2018.

Gawlicz K. (red.), Dyskryminacja w szkole - obecność nieusprawiedliwiona. O budowie edukacji antydyskryminacyjnej $w$ systemie edukacji formalnej w Polsce, Towarzystwo Edukacji Antydyskryminacyjnej, Warszawa 2015.

Korczak J., Jak kochać dziecko. Dziecko w rodzinie, Rzecznik Praw Dziecka, Warszawa 2012.

Krawczak-Chmielecka A., O rozwoju praw dziecka w Polsce i na świecie, Dziecko Krzywdzone. Teoria, badania i praktyka, Vol. 16, Nr 2 (2017).

Łotocki Ł., Integracja i dyskryminacja - krajobraz 2009. Raport Instytutu Spraw Publicznych, Instytut Spraw Publicznych, Warszawa 2009.

Opracowanie Wydziału Statystycznej Informacji Zarządczej Departamentu Strategii i Funduszy Europejskich Ministerstwa Sprawiedliwości: Postępowanie mediacyjne $w$ świetle danych statystycznych sądy rejonowe i okregowe w latach 2006 - 2018 oraz I pótroczu 2019 roku, Warszawa 2019.

Piłat J., Kazańska-Piłat M., Przemoc psychiczna wobec dziecka w sytuacji rozwodu, Świat Problemów, Warszawa 2014.

Raszewska-Skałecka R., Mediacje rówieśnicze jako instrument przeciwdziałania agresji i rozwiązywania konfliktów w szkole, Mediacje ponad podziałami, Wroclaw 2013.

Siemaszko A., Ostaszewski P., Włodarczyk-Madejska J., Tendencje wpływu spraw do polskich sądów powszechnych, Analizy wymiaru sprawiedliwości, Warszawa 2019.

Wydział Statystycznej Informacji Zarządczej Departament Strategii i Funduszy Europejskich Ministerstwo Sprawiedliwości, Postępowanie mediacyjne $w$ świetle danych statystycznych Sady Rejonowe i Okregowe w latach 2006-2018 oraz I pótroczu 2019 roku, Warszawa 2019.

Akty Prawne

Deklaracja Praw Dziecka Uchwalona przez ONZ dnia 20 listopada 1959 r.

Konstytucja Rzeczypospolitej Polskiej z dnia 2 kwietnia 1997 r. (Dz. U. 1997 Nr 78 poz. 483).

Konwencja o Prawach Dziecka przyjęta przez Zgromadzenie ONZ dnia 20 listopada 1989 r. (Dz. U. 1991 Nr 120 poz. 526).

Ustawa z dnia 17 listopada 1964 r. Kodeks postępowania cywilnego (Dz. U. 2019 poz. 1460).

Ustawa z dnia 6 stycznia 2000 r. o Rzeczniku Praw Dziecka (Dz. U. 2020 poz. 141).

Ustawy z dnia 9 czerwca 2011 r. o wspieraniu rodziny i systemie zastępczej (Dz. U. 2020 poz. 821). 


\section{Netografia}

Bank Światowy, Dane statystyczne dot. tempa wzrostu liczby ludności, https://www. google.com/publicdata/explore?ds=d5bncppjof8f9_\&met_y=sp_pop_grow\&i$\mathrm{dim}=$ country:POL:ITA:SWE\&hl=pl\&dl=pl, (25.06.2020).

Bank Światowy, Dane statystyczne dot. wskaźnika płodności, https://www.google. com/publicdata/explore?ds=d5bncppjof8f9_\&met_y=sp_dyn_tfrt_in\&idi$\mathrm{m}=$ country:POL:ITA:SWE\&hl=pl\&dl=pl\#!ctype $=1 \&$ strail=false\&bcs=d\&nsel$\mathrm{m}=\mathrm{h} \& \mathrm{met}$ y=sp_dyn_tfrt_in\&scale_y=lin\&ind_y=false\&rdim=world\&idi$\mathrm{m}=$ country:POL\&ifdim=world\&hl=pl\&dl=pl\&ind=false, $(26.06 .2020)$.

Bereźnicki J., Wyprawka 300+ także dla dzieci z domów dziecka. Pieniądze będa dostawać do 20 roku życia., https://finanse.wp.pl/wyprawka-300-takze-dla-dzieci-z-domow-dziecka-pieniadze-beda-dostawac-do-20-roku-zycia-626241 4118192769a, (26.06.2020).

Ciszak P., 300+ nie dla dzieci z domów dziecka. Rzecznik Praw Obywatelskich interweniuje u ministra, https:/www.money.pl/gospodarka/wiadomosci/ artykul/300-nie-dla-dzieci-z-domu-dziecka-rzecznik,22,0,2403606.html, (25.05.2020).

Gajos-Kaniewska D., Dlaczego dzieci z domów dziecka nie sa objęte 500+ - ministerstwo rodziny wyjaśnia, https://www.rp.pl/Praca-emerytury-renty/ 307169957-Dlaczego- dzieci-z-domu-dziecka-nie-sa-objete-500---ministerstwo-rodziny-wyjasnia.html, (25.06.2020).

Główny Urząd Statystyczny, Piecza zastępcza w 2018 roku, https://stat.gov.pl/obszary-tematyczne/ dzieci-i-rodzina/dzieci/piecza-zastepcza-w-2018-roku,1,3. html, (25.06.2020).

Rzecznik Praw Dziecka, Standardy mediacji rówieśniczej i szkolnej w szkołach $i$ innych placówkach oświatowych, Warszawa 2017, http://brpd.gov.pl/sites/ default/files/standardy_mediacji_rowiesniczej_i_szkolnej_w_szkolach_0.pdf, (27.06.2020).

Strona Internetowa Funduszu Narodów Zjednoczonych na Rzecz Dzieci, https:// www.unicef.pl/c ontent/download/11454/94626/ file/Microsoft_Word_-_Deklaracja_Genewska.pdf, (25.06.2020).

Strona Internetowa Funduszu Narodów Zjednoczonych na Rzecz Dzieci, https:// www.unicef.pl/O-nas/Prawa-dziecka/Geneza-praw-dziecka, (25.06.2020).

Wielki słownik języka polskiego, https://wsjp.pl/index.php?id_hasla=2711, (27.06.2020).

Ziomek W., 500 + także dla wychowanków domów dziecka. Placówki składają wnioski, https://www.money.pl/gospodarka/500-takze-dla-wychowankow-domow-dziecka-placowki-skladaja-wnioski-6401507587463297a.html (25.06.2020).

\section{Abstrakt}

Problematyka ochrony praw małoletnich stała się przedmiotem zainteresowania zarówno doktryny, jak i praktyków już w ubiegłym stuleciu. Celem niniejszego artykułu jest poddanie analizie społeczno-prawnej sytuacji dziecka w Polsce w XXI w. Temat ten wydaje się być szczególnie aktualny ze względu na fakt, iż starzejące się społeczeństwo coraz to bardziej docenia dobro narodowe, jakim są małoletnie dzieci. dążąc do zagwarantowania im jak najlepszych warunków bytowych. Ze względu na znacze- 
nie prawidłowego rozwoju dziecka i szczególną potrzebę zapewnienia ochrony praw małoletnich, należy przyjrzeć się ich sytuacji faktycznej m.in. w trakcie toczących się postępowań sądowych, spraw rozwodowych oraz konfliktów rówieśniczych, które to wywierają znaczący wpływ zarówno na rozwój psychiczny dziecka, jak i postrzeganie jego funkcji w społeczeństwie.

Słowa kluczowe: dziecko, małoletni, dyskryminacja, konflikt, mediacja

\section{The Socio-legal Situation of Children in Poland in the 21st Century. Discrimination of Minors and Methods of Resolving Conflicts Involving them}

Abstract

The issue of protection of rights of minors became of interest to both doctrines and practitioners already in the 1900s. The purpose of the article is to offer a socio-legal analysis of the situation of children in Poland in the 21st century. This subject seems to be particularly topical given the fact that aging society has increasing appreciation for its national treasure young children are seeking to ensure the best living conditions possible. Because of the significance of correct child development and the special need to protect the rights of minors, one should look at their actual situation, including during pending court proceedings, divorce cases and peer conflicts, which have a major impact on children's psychological development and perception of their function in society.

Keywords: child, minor, discrimination, conflict, mediation 